\title{
Bazı Belge ve Tanımlarla 'Çini' Kelimesinin Değerlendirilmesi
}

İrem ÇALIŞICI PALA **

Özet

'Çini' kelimesine ilişkin, Türkiye Türkçesi'nde bugüne kadar yapılmış ulaşılabilen bazı tanımlarda, 'çini' alanında bir üretici ve araştırmacı olarak, bazı çelişkiler ve yanlış yönlendirmeler saptanmıştır. Bu çelişkili bilgiler, özellikle 'çini’ alanında çalışanların, 'çini' kelimesi ile ilgili tek bir anlam altında toplanmasını engellemektedir. Ayrıca, 'çini' kelimesi, başka bir dile veya yabancı dildeki bir yayın, Türkçe’ye çevrildiğinde bazı problemlere yol açmaktadır. Bu nedenle bu çalışmada, 'çini' kelimesinin kullanımına ilişkin, ulaşılabilen bazı belgeler ve bazı güncel sözlük tanımları değerlendirilerek, 'çini' kelimesinin günümüzdeki kapsamını belirlemek hedeflenmiştir.

Anahtar Sözcükler: Çini, Seramik, Geleneksel Türk Seramiği, Fritli Çamur, Sırça, Kaşi, İznik.

\section{Evaluation of the Word 'Çini' by Certain Documents and Definitions}

Abstract

As a researcher and a producer of traditional Turkish ceramic, some contradictions and false introductions about the word 'çini' have been determined which are found in some of the definitions in present-day Turkish language. These contradictive information prevent the gathering of specialists under one meaningful title who work on 'çini'. Besides, it is porblematic when the word ' çini' intended to be translated from one language into another. For this reason, in this paper, it is aimed to underline the contemporary scope of the word 'çini' by evaluating some of its definitons in certain documents and dictionaries.

Keywords: Cini, Sini, China, Chinoiserie, Traditional Turkish Ceramic, Tile, Fritware, Stoneware. 


\section{Giriş}

'Çini' kelimesine ilişkin, Türkiye Türkçesi'nde bugüne kadar yapılmış, ulaşılabilen bazı tanımlarda, Güzel Sanatlar Fakültesi, Geleneksel Türk Sanatları Bölümü, Çini Anasanat Dalı alanında eğitim almış bir üretici ve araştırmacı olarak, çelişkiler ve yanlış yönlendirmeler saptanmıştır. Bu çelişkili tanımlar nedeni ile 'çini' alanında çalışanlar arasında, 'çini' kelimesi ortak bir anlamda kullanılamamaktadır. 'Çini' kelimesinin kapsamını belirleyebilmek için bu çalışmada, 'çini'ye ilişkin bazı yazılı belgeler, başvuru kaynakları ile sözlüklerde yayınlanan tanımlar ve kelimenin günümüzde farklı anlamlarda kullanılmasının olası nedenleri, tarih sırasıyla aktarılarak değerlendirilmiştir.

'Çini', Çin ile ilişkili bir kelimedir ve Çin'in ilişki kurduğu ülkelerde, dillerde görülmektedir. Günümüzde, 'çini' ve Çin porseleni hakkındaki araştırmaların birçoğu batı dillerinde yayınlanmıştır. Yabancı dildeki yayınların Türkçe'ye çevrilmesi, bunun yanında Türkçe bir kelimenin önce bir batı diline, oradan tekrar Türkçe'ye çevrilmesi nedeniyle 'çini' ile ilişkili özellikle bazı İngilizce kelimeleri değerlendirmek ve ilgili bazı Almanca, Fransızca kelimelere kısaca yer vermek gerekli görülmüştür. 'Çini' kelimesinin geçmişte nitelediği ürünler ile günümüzdeki pişmiş toprak üretimler için nitelediği anlamlar, ayrı bir çalışma konusu olabileceğinden bu çalışmada kapsam dışında tutulmuştur.

'Çini' ve pişmiş toprak eşyaları niteleyen kelimelerin geçmişe ait kullanımı, bazı gezginlerin ifadelerinde ve çeşitli arşiv belgelerinde görülmektedir. Ancak, geçmişte pişmiş toprak eşyaların, sıradan günlük kullanım eşyaları olmaları nedeni ile bazı gezginler veya tarih yazıcıları gibi yazılı belgelerin kaynakları, anlatımlarında bu eşyalara yer vermemektedir (Milwright, 1999: 505). Geçmişe ait ulaşılabilen belgelerin birçoğu Osmanlı Dönemi'ne aittir. $\mathrm{Bu}$ belgeler, kullanılan eşyaların listeleridir ve var olan eşyanın sadece küçük bir bölümünü aktarmaktadır (Yücel ve Raby, 1986: 68). Ayrıca bu listeleri oluşturanların, seramik uzmanı olmayan saray görevlileri olması nedeni ile benzer eşyalar için farklı terimlerin kullanıldığı görül- mektedir (Atasoy, 1989: 25). Örneğin, Çin porselenleri için 'çini'nin yanı sıra, porselen, cavi, zeytuni, guri, babaguri, alaca, sir mayi, fağfuri, mertabani gibi kelimeler de kullanılmaktadır (Raby, 1986: 85). Ayrıca, Osmanlı döneminde Arapça ve Farsça kelimelerin kullanılması, pişmiş toprak eşyalardan hangi ürünü nitelediğinin günümüzde tam belirlenememesine neden olmaktadır (Atasoy, 1989: 48). Belirtilen nedenlerden dolayı "günümüzdeki sanat eserlerinin belgelenmesi ile karşılaştırılamaz...” (Raby, 1986: 85).

Günümüzde Selçuklu Dönemi seramikleri, dekorlama tekniklerine göre sıraltı, lüster, minai, renkli sır, ajur, kazıma, mozaik, kalıp dekorlu olarak sınıflandırılmıştır. Osmanlı Dönemi pişmiş toprak ürünleri ise, üretim yerlerine göre porselenler: Çin, Uzak Doğu, Avrupa, Eser-i İstanbul, Yıldız Sarayı, seramikler: İznik, Kütahya, Tophane, Çanakkale $^{1}$, bezemesi olmayanlar ve diğer yerel üretimler olarak sınıflandırılmaktadır. Arşiv belgelerinde ise, pişmiş toprak ürünlerin form adı, işlevi, kalitesi, boyutu, rengi, bezemesi, üretildiği/geldiği yer veya türü belirtilerek adlandırıldıkları görülmektedir (Pala, 2009: 323). Fağfuri², martabani3 ${ }^{3}$ alaca ${ }^{4}$, şikeste 5 , evani 6 , beçkari7, Kütahya, pişmiş toprak kullanım eşyaları için kullanılan adlardan sadece birkaçıdır. Bu adlar, tek tek kullanıldığı gibi, 'çini fağfuri', 'büyük İznik badyası' (Atasoy, 1989: 26) gibi bir arada da kullanılmaktadır. Bu adlar arasında porseleni niteleyen fağfuri, hem Uzakdoğu hem de Avrupa porselenlerini nitelerken kullanıldığı için ayrıca önemlidir.

'Çin-î' kelimesinin sonundaki (-î) aitlik eki, “Arapça ‘şīnī', Farsça ve Türkçe ‘çīnī” 8 , üretilen ürünün ya Çin'den geldiğini ya da Çin’e atfedildiği anlamını taşımaktadır.

'Çini' kelimesinin geçmişte temelde üç anlamda kullanıldığı anlaşılmıştır:

1- Çin'den gelen eşya (hammadde olarak çoğunlukla porselen)

2- Çin porselenine benzer yerel üretimler,

3-Ayrıca Batı dillerinde (ve Memlük Eyyubiler'i Dönemi'ne ait bir belgede9 ve Kazaklar'da ${ }^{10}$ ), porselen bünye, kaolen ${ }^{11}$.

Çin porselenlerinin kullanım eşyaları olmaları nedeni 
ile geçmiş̧e 'çini', genellikle kullanım seramiklerini nitelemektedir. Mimari seramikler ise çoğunlukla sırça ${ }^{12}$ kaşi13 gibi yöresel adlarla anılmaktadır. Örneğin, Osmanlı Dönemi 'Hazine-i evrak vesikalarında', “kaşigeran, kaşici, kaşi üstadları, tuğla kaşi, kaşiciler başı, kaşi madeni taşı, kaşi, çini karhaneleri, çini” kelimelerinin kullanıldığı görülmektedir (Refik, 1932). Hammadde adı olarak, 'kaşi madeni taşı' ifadesinin kullanılması, mimari seramikler için, 'kaşi' kelimesinin 'çini' kelimesine göre daha yaygın kullanıldığını göstermektedir. Ayrıca, 'Çini’ ve 'kaşi' kelimelerinin bir arada kullanımına örnek, 1611-1682 yılları arasında yaşamış olan Evliya Çelebi'nin seyahatnamesinden alıntı yapan Ahmet Refik'te (1932: 36) görülmektedir: "Kâşiden kâseleri, tabakları, ibrikleri değerlidir. Diyarı Osmanîde ne kadar münakkaş kâşili âyine var ise kâş̧iler hep bu İnik şehrinde işlendiğinden şehrin adı da Çîni Maçini Rumdur.".

\section{1. 'Çini' Kelimesine Illişkin Belgeler}

\subsection{Porselen ve 'Çini' Kelimesi}

Uzakdoğu dışında, dünyanın başka bir yerinde, porselen üretilinceye kadar Çin porselenleri ulaştığı yerde çok değerli kabul edilmiştir. ${ }^{14}$ Bunun en önemli nedeni, ürünün porselen olmasıdır. Pişmiş toprak türlerinden porseleni üretebilmek için öncelikle, hammadde gerekmektedir. $1200{ }^{\circ} \mathrm{C}$ 'ye dayanamayan seramik ürünlerin aksine porselen, bu derecelerde pekişmeye başlamaktadır. "Çin'de porselen üretiminin, M.0̈. 4. yüzyılda başladığına dair belgeler bulunmaktadır...." (Arcasoy, 1982: 19). Dünyada ise teknik açıdan ${ }^{15}$ porselen tanımına uyan ilk imalat, Çin'den yaklaşık 1000 yıl sonra “Avrupa'da 1709 yılında, Almanya Meissen'de üretilmiştir.” (Tufan, 2005: 75). Bu nedenle, dünyada 1000 yıl boyunca, Çin porseleni özellikli ve değerli görülerek, bünye ve görsel olarak benzerleri üretilmeye çalışı ımıştır.

Çin porselenleri, iki alanda dünya seramiğini etkilemiştir. Bunların birincisi bünyesi, diğeri ise başta dekoru olmak üzere görselliğidir. Porselen bünyeye benzer üretimler, günümüzde 'fritli bünye', 'fritli çamur', 'sırçalı çamur, 'kuvarslı bünye', 'fritware', 'fayans (faience)', 'kashi', 'stoneware', 'stonepaste' (Mason ve Tite, 1994: 33), 'sini', 'çini' olarak adlandırılan üretim teknikleridir. Özellikle Müslüman seramikçiler tarafından geliştirilen bu üretim tekniği sayesinde kuvarsı cam ile birleştirerek düşük derecede porselen gibi pekişmiş bir bünye elde edilmiştir. Çin porselenlerine benzer üretimler ise, bazı form özellikleri dışında (tabak kenarının dilimlenmesi gibi), çoğunlukla, mavi beyaz dekorlu örnekler taklit edilmiş veya esin kaynağı olmuştur. Bu tür benzer seramikler, şekillendirilen yerel kirli çamurun, çamurla (astar olarak) veya sırla beyazlaştırılmış yüzeyine, mavi (kobalt bileşikleri) renkle, Çin porseleninde bulunan bir kompozisyon, bir motif veya ustanın kendi kültürel beğenisini yansıtan dekorlarla üretilmiştir. Bu nedenle bu ürünler, kültürel yorumlar veya coğrafi farklılıklar nedeni ile çok çeşitlilik gösterir. ${ }^{16}$

Uzak Doğu ile Batı arasındaki ticari ve kültürel alışverişi sağlayan İpek Yolu, Çinliler tarafından M. Ö. 136'da başlatıımıştır (Roux, 2001: 31). Değerli Çin ipeği, baharatı ve porseleni, deniz ticaretinin gelişmesine kadar bu yolla taşınıyordu. “Yakın Doğu’ya Çin etkilerinin ilk dalgası, 9. yüzyılda, ikincisi 12. yüzyılda, üçüncüsü ise 15. yüzyılda olmuştu." (Lane, 1948: 3). "Yakın Doğu’da erken dönemlerde, Çin porselenlerinin, tanınmış değerli görülmüş ve rağbet duyulmuş olduğu bilinse de, Selçuklu ve ilk Osmanlı Dönemi Saraylarındaki varlıkları bilinmemektedir." (Ünal, 1963: 679). "Çin porseleni, Osmanlılarda 1410 veya 1420'lere kadar, az bulunur bir maldı ve azda olsa görülmesi ancak Sultan sofralarında mümkündü." (Raby ve Yücel, 1986: 28). Birinci Mehmed (1413-1421) döneminde, Osmanlı tarihçisi Aşık Paşazade'nin katıldığı vezir ziyafetinde, 'siniler'in kullanıldığı belirtilmektedir (Raby ve Yücel 1986: 27; Erdoğdu, 2001: 106). Ancak, buradaki ‘sini’ kelimesinin Çin porseleni veya Çin porseleni benzeri yerel üretim için kullanılıp kullanılmadığı açık değildir. Çin porselenlerinin Osmanlılar'da Fatih Sultan Mehmed döneminde kullanıldığı ise, dönemin önemli olaylarını kaydeden Misırlı Tursun Bey'in, 1457 yılı Fatih Sultan Mehmed'in şehzadeleri Bayezid ve Mustafa için Edirne'de yapılan sünnet düğününde, "şeker şerbetleri fağfuri kıymetli üskürelerle davetlilere sunuldu” ifadesindeki 'fağfuri' kelimesinden belli olmaktadır (Ünal, 1963: 680; Kut, 2010: 76). 
Osmanlılarda, yüzyıllar boyunca Osmanlı sarayı ve çevresi tarafından bir statü sembolü olarak görülen, kullanmak için biriktirilen, bu nedenle saraya sürekli girip çıkarak değişen (Erdoğdu, 2001: 100,102; Raby ve Yücel, 1986: 27) ve günümüzde Topkapı Sarayı Müze'sinde bulunan Çin porselenleri, 1300 ile 1900 yılları arasındaki üretimleri kapsamaktadır (Krahl, 2001: 44). Topkapı Sarayı Müzesi Çin Porselenleri Kataloğu'nda, en eski üretim tarihine sahip olan porselen seledon çanak (TKS 15/235) 13. yüzyıla aittir (Krahl, 1986: 209). Mavi- beyaz Çin porselenlerin en eskisi ise, 14 . yüzyılın ortalarına tarihlendirilmektedir (Krahl, 1986: 386).

Avrupa ise Çin porselenini, 13. yüzyıl sonunda Marco Polo aracılığı ile tanımıştır (Sadberk Hanım Müzesi Kataloğu, 1995: 117). Ancak, Avrupalı soylular ve zenginler arasında pahalı bir tutkuya dönüşen Ming porselenlerini toplama merakı, 1609'da kurulan Doğu Hindistan Hollanda Şirketi sayesinde başlamıştır (Küçükerman, 1987: 20).

Çin porselenleri, ulaştıkları yerlerde çok değerli oldukları için, Perslerde ve Orta Asya'da, en erken örnekleri 15. yüzyıla tarihlenen 'chini- khaneh'de (porselen evi) korunuyordu ve İran'daki Ardabil koleksiyonu için de 'chini- khaneh' yapılmıştı (Bailey, 1996: 13). Osmanlılarda ise Çin porselenleri, Topkapı Sarayı'nda bulunan, Fatih Sultan Mehmed tarafından yaptırıldığı söylenen 'oda-yı çini’de depolanmaktadır. Burada ayrıca altın gümüş gibi diğer değerli kap kacaklar barındırılmaktadır (Necipoğlu, 2007: 103). Avrupa'da ise 17. yüzyılın son çeyreğinde 'Çin odası' olmayan, 'Çin porselenleri dolabi' bulunmayan hiçbir saray ve hiçbir büyük ev yoktur (Küçükerman, 1987: 20).

\subsection{Yerel Üretim 'Çini' ve 'Çini' Kelimesi}

'Çini' kelimesi ile ilişkili ulaşılabilen en erken tarihli belgede, 'Al- Tha'alibi'de (961- 1038), Çin sanat eserlerinin prestiji nedeni ile Arapların, alışılmadık tüm eşyalara ‘şīnīyya' dediğini belirtilmektedir (Raby, 1986: 82). “Müslüman seramikçilerin, yaptıkları ürünlere alışkanlıkla 'sini' (china) adını vermeleri, bu ürünleri, Çinlilere borçlu olduklarını göstermektedir." (Lane 1971: 21; Carroll 1999: 180).

“Batı'ya ulaşan Çin porselenlerinin ilk örnekleri, Çin- lilerin kendi beğenileri için ürettikleri ding, qingbai ve seledon gibi tek renkli sırlı ürünlerdi. Çinliler, Çin porselenleri ile dünyaya yayılan mavi beyaz ürünlerin ise düşük kalitede $^{17}$ ve Çin üslubunda olmadığını düşünüyorlardı. Çin'de mavi beyaz porselen üretimi, Çin'e Moğol fatihleriyle gelen, Müslüman toplumun ihtiyaçlarını gidermek amacı ile başlamıştır." (Bailey, 1996: 7). "Sır altına kobalt bileşikleri ile dekorlama ilk defa 12. yüzyılda İran'da kullanılmış, İranlı tüccarlar tarafından kobalt madeni Çin'e götürülmüş ve ithal edilen kobaltla ilk mavi beyaz Çin porselenleri üretilmiştir. 14. yüzyıl porselenlerinin tümünde ithal kobalt kullanıldığını kimyasal analizler belirlemiştir." (Erdoğdu, 2003: 88). “Müslüman pazarın isteği doğrultusunda üretilen mavi beyaz Çin porselenlerinin, İslamî benzer üretimleri ise 14. yüzyıldan sonra başlamıştır." (Golombek, 1996: 3). "Çinliler, klasik Yuan mavi beyazları, 1320'ler 1351'ler arasındaki otuz yıllık süre içinde üretmiştir." (Bailey, 1996: 8).

1320'lerden önceki Çin porselenlerinin tek renkli ürünler olması nedeni ile 11. yüzyılda, İslam topraklarında, Çin porseleni dışındaki ilk 'çini' ürünler, tek renk kurşunlu sırlı kazıma dekorlu ve kurşunlu sırlı rölyef dekorlu (Lane, 1948: 12), kırmızı veya fritli bünyeli yerel üretim kullanım seramikleridir. Anadolu üretimlerinde de kazıma dekor ve tek renk sırlı örneklerin bulunduğu, ilgili arkeolojik kazı raporlarında ve ilgili yayın (Anadolu'da Türk Devri Çini ve Seramik Sanatı, 2007) ve müzelerde görülmektedir. Bu seramikler çeşitli seramik merkezleri tarafından üretilmekteydi. “12.-13. yüzyıl Anadolu Selçuk seramikleri stil ve üslup bakımından birbirlerinden ayırt edilemeyecek kadar benzerlik gösterdiklerinden bir bütün olarak değerlendirilmeleri gerekir. Anadolu seramikleri genelinde, Mısır'da ve Suriye'de 11.-13. yüzyıllarda gelişen seramik ekolünün uzantısı durumundadır. Tek renk firuze, yeşil, kirli sarı, kahverengi ve patlıcan şeffaf sırlı seramikler Anadolu'nun her yöresinde karşımıza çıkmaktadır." (Öney, 1987).

Osmanlı döneminde en önemli yerel seramik üretim merkezi İznik'ti. Dolayısıyla İznik seramikleri, 'çini' olarak adlandırılabiliyordu; hatta, Atasoy (1989: 25), 
"Osmanlı kapları ise yalnızca çini olarak anılmıştır" şeklinde belirtmektedir. 1331'de Osmanlı yönetimine geçen İnik'te (Osmanlı Seramiklerinin Görkemi, 2000: 43), 1470’e kadar sadece, günümüzde, ‘Erken Osmanlı Dönemi seramiği', 'Beylikler Dönemi seramiği', 'Milet işi' gibi adlarla18 bilinen seramikler üretilmekteydi. Bunlar dışında, İnik'te, Fatih Sultan Mehmed döneminde başlayan ve $1717^{\prime} l e r d{ }^{19}$ son bulan, ilk olarak kullanım seramiklerinde kullanılan fritli çamur teknolojisidir. Mavi beyaz İznik fritli çamur üretimleri hem bünye hem de görsel olarak Çin porselenlerine benzemektedir. İznik'te, Çin porseleni benzerlerinin fritli bünyeler yanısıra kırmızı çamur bünyeye de uygulandığı, 15. yüzyılın ilk yarısına tarihlenen, mavi-beyaz Çin porseleni desenli kase parçasından (1981 yılı kazı envanter no: 6) anlaşıılmaktadır (Pala, 2006).

Osmanlı Sarayında, İznik seramiklerine ait ulaşılabilen en eski arşiv belgesi, İkinci Bayezıd (1481-1512) dönemine aittir. "1496'da yapılan bir envanterde, çok sayıda Çin porseleni yanısıra bir tane de 'Iznik'e rastlanır” (Atasoy, 1989: 29). Çin porselenleri ile İznik seramiklerinin beraber korunduğu, “...1582'de Atmeydanı'nda şehzadelerin sünnet dügününde kullanılan İznik ve Çin seramikleri de aynı "çini anbarı'ndan ödünç alınmıştır” (Necipoğlu, 2007: 103) ifadesi ile belirtilirken, iki ürün arasındaki karşılaştırmayla “16. yüzyıla ait muhallefat defterleri'nden, İznik kaplarının Çin porselenlerine oranla çok ucuz olduğu anlaşılmaktadır." ifadesinde karşılaşılır (Atasoy, 1989: 27).

Osmanlı dönemine ait bazı belgelerde, İznik çinisi ile Çin porseleni veya Kütahya ayrı ayrı belirtilse de, bazı listelerde 'çini' başlığı altında çeşitli pişmiş toprak eşyaların sıralandığı görülmektedir. “...Belli bir dönem içinde İstanbul'da üretilen kaplarla İznik'te üretilenler arasında bir ayrıma gitmek gereksizdir. Farklılıkları ortaya koyabilecek başka belgeler ya da kanıtlar bulununcaya deyin belgelerde adı geçen bütün, 'çini’ ve 'İznik çinileri'ni aynı başlık altında değerlendirmek daha doğrudur." (Atasoy, 1989: 25). Bu düşünce, yerel üretimleri, 'çini' başlığında toplamak açısından geçerli bir yaklaşımdır. Ancak, ‘çini'nin, yukarıda belirtilen belgelerde de görüldüğü gibi,
‘Çin’den gelen' anlamını taşıması ve ilk dönemlerde Çin porselenlerini belirtmesi ve ayrıca Osmanlı Dönemi saray çevresinde kullanım eşyası olarak Çin porselenlerinin 'İznik çinisi’ne göre daha çok tercih edilmesi nedeniyle, belgelerde geçen 'çini' kelimesini sadece yerel üretim olan 'İznik çinisi’ olarak değerlendirmemek gerektiği düşünülmektedir. “Sultan'ın şahsi yemeğinin hazırlandığı 'Has Matbah'ta 'Serçini' veya 'Çinicibaşı'nın bu mutfağın başı olduğu ve görevleri arasında servis için gerekli 'çini'lerin sorumluluğunun da bulunduğu ...." (Raby ve Yücel, 1986: 41) ifadesinde geçen 'serçini veya çinicibaşı' ile yukarıda belirtilen, “oda-yı çini” (Necipoğlu, 2007: 103), ve Birinci Mahmud (1730 - 1754) Dönemine ait, "Çinihane defterleri" (Tufan, 2005: 22) ifadelerinden, Osmanlı döneminde 'çini' kelimesinin, idari ve mimari birim adlandırmalarında da kullanıldığı görülmektedir. Bu durumla birlikte, 'çinicibaşı'ların sorumlu olduğu pişmiş toprak eşyalar, yukarıdaki belgede, 'çini' olarak adlandırılmıştır. Bilindiği gibi saray öncelikli olarak herkesin kolaylıkla sahip olamadığı yabancı ürünleri tercih etmekteydi. Dolayısıyla belgelerde geçen bütün 'çini'lerin, sadece İznik seramiklerini değil, diğer bazı değer verilen pişmiş toprak eşyalarla beraber, Çin porselenlerini de kapsayan bir anlamda kullanılması gerektiği düşünülmektedir. Ayrıca, “'Çīnī kelimesinin, porseleni20 olduğu kadar seramiği de21 tanımladığı" (Raby, 1986: 82) belirtilse de, Osmanlı belgeleri dışında, resmi dili Arapça olan Eyyubi Dönemi'ne ait 15-16. yüzyıl belgelerinde 'çini' kelimesinin genellikle Çin porselenlerini nitelediği görülür. 22

\subsection{Avrupa Porseleni ve 'Çini' Kelimesi}

Osmanlı İmparatorluğu'nda Çin porselenlerine gösterilen yoğun ilgi, Avrupa'da porselenin keşfedilip ithal edilmesine kadar büyük bir hızla devam etmiştir (Sonat, 2005: 13). "Avrupa porselenleri (frengi fağfuri), saray belgelerinde ilk kez 1733 tarihinde görülür." (Raby ve Yücel, 1986: 53). Osmanlı Imparatorluğu'na, Avrupa porseleni seri ihracatı, Birinci Abdülhamid (1774-1789) Dönemi'nde başlamıştır (Keribar, 1998: 88). Osmanlı belgelerinde Avrupa porse- 
lenlerinin çoğunlukla fabrika adları ile adlandırıldığı görülmektedir 23 ve Osmanlı sarayında birçok markada Avrupa porselenleri bulunmaktadır (Küçükerman, 1987: 53).

Avrupa'da ve Osmanlı'da, porselen üretiminden sonra 'çini' kelimesinin tanımladığı ürünlerin artık sadece, Çin porseleni veya Çin porseleni benzeri yerel üretimlerle sınırlanmadığı, daha da çeşitlendiği görülmektedir. 18. yüzyılın sonları, Osmanlılarda, sanatta Batı etkisinin yaygınlaşmasının başlangıcı olarak kabul edilmektedir (Küçükerman, 1987: 60). “Eser-i İstanbul, İstanbul'da 3. Selim Döneminde (1789-1807) yapılan bir cins ince porselendir... Eyüp ve Beykoz camcıları yanında, çini ve çömlek yapan ustaların zaman zaman 'günlük porselen' yaptıkları da söylenir." (Küçükerman, 1987: 53). 1939 yılına ait alıntıda, yerel bir ürün olan, Eser-i İstanbul porselenleri anlatılırken, "çini, çömlek ve porselen" in ayrı ayrı belirtilerek, farklı ürünler olduklarının nitelenmesi ayrıca dikkat çekicidir. Bu yayın 'çini' kelimesinin günümüzdeki çeşitli anlamlarda kullanılmasına ait bir geçiş özelliği taşımaktadır. 'Çini' kelimesinin farklı kullanımının önemli nedenlerinden biri olarak ise, İkinci Abdülhamid Dönemi'nde, Osmanlı Sarayı himayesinde porselenin, 1890-92'de 'Yıldız Çini Fabrika-i Hümayunu', 'Yıldız Çini Fabrikası' adıyla üretilmeye başlanması gösterilebilir. Fabrikanın adı, 1959 yılında 'Sümerbank, Yıldız Porselen Sanayii Müessesi' ve 1961 yılında, 'Yıldız Çini Ve Porselen Sanayi Müessesesi' olarak değişmiştir (Bayram 1984:102; Küçükerman 1987: 53).

"Avrupa, ürettikleri ilk porselenleri 'China veya porcelane' olarak adlandırıyordu." (Chaffers, 1867: 433) ve kurdukları porselen fabrikası isimlerinde, 'Chelsea China' örneğinde olduğu gibi ‘China' kelimesini, porseleni niteleyen anlamda kullanmaktaydı. 'Yıldız Çini Fabrikası'nın kuruluşunda "Avrupa'dan destek alan" (Küçükerman, 2002: 78), Osmanlı yöneticilerinin de 'Yıldız Çini Fabrika-yı Hümayunu' ismini verirken, 'çini' kelimesini, Avrupalılar gibi 'porselen' anlamında kullanmış olduğu görülmektedir. 1910 yılında Yıldız Çini Fabrikası, Müze-i Hümayun Müdürlüğüne bağlı iken, müze Müdürü olan Halil Edhem Bey, “'çini fabrikası' ismini taşıyan fabrika, çiniden daha çok porselen üretmektedir" (Küçükerman, 1987: 75) diyerek, 'çini'nin, teknik bir özellik anlamında olduğunu hatırlatmaktadır. Bu da günümüzde Türkçe’de kullandığımız 'çini' kelimesinin farklı anlamlarda kullanılmasının, Batıılaşma sonucu 'Yıldız Çini Fabrikası' adıyla başladığını gösterir niteliktedir. Ancak, fabrikanın kuruluş aşamalarında Fransız Sevres fabrikasından yardım alınmıştır. Türkçe-Fransızca sözlükte, 'çini' kelimesinin karşılığı, 'faïence' olarak geçmektedir; (Fransızca Türkçe Sözlük, fransizcasozluk. gen.tr, 2012b) ve Delft kullanım seramiklerinin de 'fayans' olarak adlandırıldığı görülmektedir (Sevres ceramique, sevresciteceramique.fr, 2012). 'Fayans' kelimesi ileride, tekrar kısaca ele alınmaktadır.

Günümüz sözlük tanımlarına geçmeden önce, 'çini' kelimesinin, Türkiye Cumhuriyeti'nin ilk yıllarında hangi anlamlarda kullanıldığını örneklemesi açısından aktarılması gerekli görülen, Topkapı Sarayı Müzesi Tahrir Komisyonu Çalışmalarında yer alan 'çini' ve bazı 'Çin' kelimelerine yer verilmesi uygun görülmüştür. Bu çalışmalar, "1924 tarihinde Müze haline getirilen Topkapı Sarayı ve müştemilatında bulunan yapıların içindeki eşyanın tespiti için, Müzeler Müdiriyyet-i Umumiyyesi'nin emriyle kurulan komisyonun eski harflerle kayıt ettikleri defterlerdir. Bunlar, Topkapı Sarayı Müzesinin ilk envanter kayıtları sayılabilir. Bu belgelerde, bugünkü yeni envanter kayıtlarında bile bazen rastlayamadığımız deyimlere rastlanmaktadır." (Altındağ, Bayraktar, 1987: 22- 24 ve 1988: 49, 50, 30 - 32). Çin porselenlerinin, ayrıca belirtildiği bu kayıtlarda yer alan 'çini'ler şöyledir: "çini, Kütahya çinisi, Çin mamulatından mertebani tabaklar, çini taklidi, Çin mamulatından Delft ve Portekiz tabir olunanlar, desti (beyaz üzerine mavi çiçekli tabaksız Buhara işi), Çinkari, Çini fabrikası, tabak mai beyaz çini, vasat çini, çini yemek payatası, çini çerçeve (Çini fabrikası)" (Altındağ ve Bayraktar, 1987: 7). 1924 yıllarında yapılan bu adlandırmalarda önceki dönemlere göre daha güncel isimlendirmenin yapıldığı görülmektedir. Bu çeşitlilik içinde, 'Çin mamulatı' ve 'çini taklidi' ifadeleri ile Çin porselenleri ve yerel üretimlerin birbirlerinden net olarak ayrıldığı görülse de, 'çini' olarak isimlendirilen 'Yıldız Çini Fabrikası' 
ürünleri porselendir ve bezemede, birçoğu Çin porselenlerinden farklıdır. Bu nedenle Cumhuriyetin ilk yıllarında, 'çini' kelimesinin, yukarıda belirtilen, Çin'den gelen ve Çin porseleni benzeri yerel üretim anlamlarından uzaklaştığı görülmektedir.

\section{Günümüz Sözlüklerdeki ve Kaynak Yayınlardaki 'Çini' Tanımları}

Bu çalışmada 'çini' kelimesi, porselen olmayan, yerel üretim mimari seramikler ile kullanım seramikleri, bir bütün olarak değerlendirilmektedir. Ancak, ulaşılabilen Türkçe sözlük ve başvuru kaynaklarının hemen hepsinde, belirgin hatalı tanımlamalar, pişmiş toprakla ilişkili hatalı bazı teknik yönlendirmeler ve anlatımlar bulunmaktadır. Bu hatalı teknik bilgilerin, tek tek ele alınarak değerlendirilmesi gerekmektedir; bu değerlendirmenin başka bir çalışma konusu olabileceği düşünülerek bu çalışmada buna yer verilmemiştir. Ulaşılabilen Osmanlıca- Türkçe sözlüklerde24 ise 'Çini' kelimesinin bu çalışma kapsamındaki anlamı ile tanımlandığı görülmektedir.

'Çini' kelimesine ilişkin ulaşılabilen, kaynak yayın ve sözlük tanımlarındaki çeşitli teknik problemler dışındaki hatalı yönlendirmeleri, genelde, iki başlık altında toplanabilir. Bunlardan birincisi 'çini'nin sadece mimari seramiklerle sınırlandırılması; ikincisi ise porselen ile karıştırılarak aktarılmasıdır.

Atasoy (1989: 48) 'çini'nin sadece mimari seramik olarak tanımlanmasının nedenini şöyle belirtmektedir: “Arapça ve Farsça kaynaklı olan, Osmanlılarda kullanılan bu dil, tanımlamalar açısından kesin ve açık olmaktan uzaktı. Zaman içinde sözcüklerin anlamı değişikliklere uğradı. Örneğin, Osmanlıca ‘toprak kap' anlamına gelen 'çini' bugün artık 'duvar çinisi' yerine kullanılmaktadır." Oysa, yukarıdaki belgelerde de görüldüğü gibi, 'çini' öncelikli olarak kullanım seramikleri için kullanılan bir kelimedir.

Ulaşılabilen Türkçe sözlükler arasında, Türkçe'nin kaynaklarından Türk Dil Kurumu sözlüğü de (Türk Dil Kurumu Sözlüğü, tdk.gov.tr, 2008) 'çini’ maddesini sadece mimari seramiklerle sınırlayarak tanımlamaktadır 25. Buna karşılık, internet sözlüğü denilebilecek ve doğru ya da yanlış bilginin kolaylıkla çoğaltıldığı, bilgilerin bilimselliğinin sorgulanmadığı, popüler bir site olan 'wikipedia' daki (Wikipedia, tr.wikipedia.org, 2008) 'çini' tanımında, sevindirici olarak mimari seramiklerle beraber kullanım eşyaları tanımlanmaktadır.

'Çini' kelimesine ait bir kargaşanın olduğu, ansiklopedik bilgi kaynaklarından 'Ana Britannica' (1992: 476) dan örneklenebilir. Burada, 'çini' maddesi: "pişmiş topraktan yapılan, levha biçiminde, bir yüzü renkli sırlı duvar kaplama malzemesi. Sözcük geniş anlamda, aynı biçimde yapılan tabak, kase, testi gibi çanak çömlek içinde kullanılır. Osmanlılar levha halindeki çini için kaşi, çanak çömlek içinde çini sözcüklerini kullanarak bu iki türü biri birinden ayırmışlardır. Bu kullanımın köklerinde çini levhanın Anadolu'ya İran'dan (Kaşan kenti önemli bir çini merkeziydi), çini çanak çömleğin de Osmanlılar’a Çin'den gelmesi yatmaktadır" diye tanımlanmaktadır, ama tanımın devamında, mimari Türk seramiklerinin tarihçesi aktarılmaktadır. Bu tarihçenin sonunda ise, "ayrıca, bkz. Fayans" diye bir yönlendirme bulunmaktadır. Aynı ansiklopedide, kullanım seramikleri için de, "bkz. çanak ve çömlek" diye yönlendirmektedir. Ana Britannica'nın yönlendirmeleri dışında, 'çini' maddesi altında yapılan yukarıdaki tanım, bu çalışma kapsamındaki 'çini’yi en iyi tanımlayan kaynak olmuştur. Yönlendirmeler ile tanım beraber değerlendirildiğinde ise oluşan kargaşa açıktır.

'Çini'nin sadece mimari seramiklerle sınırlanmasına ilişkin ulaşılabilen en erken tarihli kullanım, Mimar Şehabeddin'in 1930 tarihli ‘Selçuki ve Osmanlı Çinileri Işsçiliği' başlıklı yayınıdır. Mimar Şehabeddin bu yayınında, İslam seramikleri hakkında yapılmış ilk yayınlardan yararlandığını belirtmektedir. Yararlanılan bu yayınların da Batı dillerinde olduğu görülmektedir.

Çini alanında çok emeği olan ve bu konuda temel bilgileri sunan saygıdeğer hocalarımız Oktay Aslanapa (1997), Ara Altun, John Carswell, Gönül Öney (1991), Faruk Şahin gibi araştırmacılar tarafından ve 6- 11 Temmuz 1986'da Kütahya'da düzenlenen Birinci Milletlerarası Türk Çini ve Seramik Kongresi26 gibi toplantılarda 'çini' kelimesi, mimari seramiklerle sınırlandırılarak, kullanım eşyala- 
rı 'seramik' başlı̆̆ı altında değerlendirilmektedir. Ayrıca, Oktay Aslanapa, Sayın Faruk Şahin ve bu kaynaklardan alıntı yapan diğer bazı araştırmacıların yayınlarında, seramiğin Almanca telaffuzu kullanılarak, 'keramik' başlığında, kullanım seramikleri ele alınmaktadırlar. Bu durum, 'keramik' ile 'seramik'in aynı şeyleri nitelediğini henüz bilmeyen, 'çini' alanında yeni çalışmaya başlayanlarda başka bir kavram kargaşası oluşmasına neden olmaktadır.

'Çini' tanımı ile 'porselen' tanımının iç içe geçtiği anlatım, Faruk Şahin’in (1983: 12-13) ‘Seramik Sözlüğü’ çalışmasında görülmektedir. Bu yayında 'çini', üç madde olarak ele alınmaktadır. Ancak, bu üç maddenin de, bu çalışma kapsamındaki 'çini' yi tanımlamadığı görülür. Şahin'in, 'çini' tanımında, birinci madde de tanımlanan ve Marco Polo’nun getirdiği pişmiş toprak türü porselendir. Burada, ‘Çin'den gelen' anlamında kullanıldığı düşünülse de, 'Çin Porselenleri'nin 'Çini' olarak adlandırıldığı tarihin 11. yüzyıla dayandığı yukarıdaki belgelerde görülmektedir. Tanımın ikinci maddesinde mimari seramiklerle sınırlı bir aktarım bulunmaktadır ve üçüncü maddesinde ise "günümüzde çini, Kütahya'da yapılmaktadır" diye belirtilmektedir; Sayın Şahin'in bu yayınının, 1983 yılına ait olması nedeni ile günümüzde yani 2014 'te, Kütahya'da üretilen seramik malzemesi ile (beyaz seramik çamuru, ilk pişirimi yapılmış formlar, sıraltı dekor boyaları ve sır) üretim yapan, Avanos, Selçuk gibi turistik yerler veya İznik üretimleri ve diğer bazı üretimlere yer verilememiştir.

'Çini' tanımı ile 'porselen' tanımının iç içe geçtiği diğer tanımlamalar ise Nurhan Atasoy (1989: 25)27 ve Eczacıbaşı Sanat Ansiklopedisi'nde (1997: 408) görülmektedir. Bu iki yayının ilkinde, Osmanlıların kullandığı 'çini' kelimesi, hatalı olarak, İngilizcedeki nitelikli yemek takımı ile eşleştirilmektedir. 'Eczacıbaşı Sanat Ansiklopedisi'nde ise seramiğin tanımlandığı, fakat porselenin nitelendiği görülmektedir. Bu problemin, çeviriden kaynaklandığı düşünülmektedir. Çevirmenlerin, İngilizce 'China' 28 kelimesini, "Çin ile ilişkili ürünler" yanı sıra, "porselen bünye"29 anlamında olmasını dikkate almadan, çevirmeleri sonucu, 'çini' ile ‘porselen'in iç içe tanımlandığı düşünülmektedir.

‘Çini’ kelimesi ile ilişkili bir başka problemle ise,
Türkçe olan bir kelimenin İngilizce'ye oradan tekrar Türkçe'ye çevrilmesi sırasında karşılaşılmaktadır. Örneğin, bu durum, 1331 yılına ait bir belgede görülmektedir. 14. yüzyılda İbn Batuta (1304-1369), (ibn Batuta’ya Göre Anadolu'nun Sosyal- Kültürel ve Iktisadi Hayatr ile Ahilik, 2001: 48) 1331'de Aydınoğulları Beyliği Birgi Sarayında, kendi adına verilen resmi kabulü anlatırken: “...şerbetle doldurulmuş çini kaselerde ortaya konmuştu” diye belirtmektedir. Raby ve Yücel'in (1986: 27) yayınında, buradaki 'çini' kelimesinin İngilizce’ye ‘porselen’ olarak çev rildiği görülmektedir. Raby ve Yücel'den alıntı yapan Ayşe Erdoğdu'nun (2001: 106) yayınında da belgedeki 'çini’ kelimesi, 'porselen' olarak kullanılmıştır. Daha önce de belirtildiği gibi, 14. yüzyıl, Yuan Dönemi mavi beyaz üretildiği ve Çin'de ticaretin desteklendiği yıllar olsa da, 14. yüzyılda Çin porselenine ulaşımın zor olması ve Çin porselenlerine benzer yerel üretimlerin de 'çini' olarak adlandırıldığı değerlendirildiğinde, İbn Batuta'nın bahsettiği çinilerin, yerel üretim seramikler olma ihtimali güçlenmektedir. İbn Batuta'nın bahsettiği çinilerin, Çin porseleni veya yerel üretim çiniler olup olmadı̆̆ının anlaşıııması için Aydınoğulları Beyliği'nde Çin porseleni kullanımına ilişkin, daha çok belgeye ulaşmak gerekmektedir. Ama çevirilerde, anlam kaybolmasına neden olmamak için, belgelerdeki 'çini' kelimesinin hangi pişmiş toprak türünü belirttiği netlik kazanmadan çevrilmemesi gerektiği düşünülmektedir. Böyle bir çeviri kargaşasının, Timur Dönemine ait belgelerde de olduğu görülmektedir. “Timur sarayında ünlü bir çömlekçinin oğlu olan Mani: babası başkalarından üstün bir seramikçi (kaseh-gar) olarak 'porselen wares (chini)' üretmesi ve....” (Golombek, 1996: 135). Bu belge değerlendirilirken, Timur Döneminde İran'da porselen üretimi bulunmadığı, bunun yerine fritli çamur veya çömlekçi çamuru ile yapılmış Çin porseleni benzer üretimlerin de ‘çini' olarak adlandırıldığı hatırlanmalıdır.

'Çini'nin Türkiye Cumhuriyeti Türkçesi öncesindeki anlamlarından uzaklaşmasına bir başka neden olarak, Türkçeleştirme çalışmaları gösterilebilir. Örneğin, 
Atasoy'un (1989: 32), 1526 tarihli bir belgede geçen "kaşigeran” ifadesini “..bir çini ustası (kaşigeran)..." olarak ve Refik'in (1938) belgelerdeki bütün 'kaşi' kelimelerini 'çini' olarak Türkçeleştirmesi gibi kullanımlar, 'çini' kelimesinin zamanla mimari seramiklerle sınırlanmasının nedenleri arasında gösterilebilir. Ancak, burada tartışılması gereken bir durum bulunmaktadır; bu da, Sait Aykut'un Ibn Battuta Seyahatnamesi (2010) başlıklı çalışmasında da 'kaşi' kelimelerini 'çini', "kaşani türünden çiniler" (Aykut, 2010: $335,384,480$ ) olarak belirtmesine rağmen, bu çalışmanın, Türkiye Yazarlar Birliği tarafından, 2004 yılında, 'yılın tercüme ödülü'nü almış olmasıdır.

'Çini' kelimesine ait bir başka problem ise, Türk kültürünü yansıtan 'çini'lerin, başka bir kültür için başka bir dile çevrilmek istendiğinde tam anlamı ile ifade edilememesidir. Örneğin, 'çini' İngilizce'ye çevrilmek istendiğinde, Türkçe-İngilizce sözlüklerde, 'tile’30, 'encaustic31 (veya glazed) tile', 'glost'32 ve 'china' ile 'chinoiserie'33, 'porcelain' (Türkçe- İngilizce Langenscheidt Standard Sözlüğü, 1983: 85) kelimeleri karşımıza çıkmaktadır. Özellikle günümüz Kütahya seramiği üreticileri, 'çini' alanında çalışanlar ve hatta 'Milli Saraylar Yıldız Çini ve Porselen İşletmesi'34 'çini'nin İngilizce karşılığında hatalı olarak, 'tile' kelimesini kullanmaktadır. Oysa ki, 'tile', Türkçe'de kullandığımız genel anlamı ile Çin'den gelen anlamını taşımadığı gibi, sadece mimari seramikler için kullanılan bir kelimedir. Fransızca kökenli 'chinoiserie' 35 kelimesi, Sözen ve Tanyeli'nin (1994: 52) çalışmasında, Avrupa ve 18-19. yüzyılla sınırlandırılsa da36, Golombek, Mason ve Bailey tarafından, İran'da Timur Dönemi üretilen Çin porselenlerine benzer yerel üretimler için ve Yıldırım ile Işmal'in (2010: 32) tekstil alanındaki çalışmalarında Chinoiserie kelimesi, Çin tarzında anlamında kullanılmaktadır. Emerson, Chen, Gates, Porcelain Stories isimli çalışmasında ise "Chinoiserie kelimesinin, 17. 18. yüzyıllarda bilinmediği ve ilk olarak 1880'de Dictionnaire de l'Academie de görüldüğü” belirtilmektedir (2000: 194).

Parantezlerdeki Türkçe karşılıkları ile 'çini' kelimesi Almanca' da şu kelimelerle ifade edilmektedir: "fliese, kachel, fayence (çini, fayans), platte (çini, fayans, levha, plaka, tepsi), majolika (çini), keramik (çömlekçilik, seramik, seramik eşya, pişmiş toprak, çini)." (Almanca Türkçe Sözlük, almancasozluk.web.tr, 2012) Anlam kargaşasına bir başka neden olarak ise 'fayans' kelimesinin TürkçeAlmanca ve Türkçe-Fransızca sözlüklerinde 'çini' maddesi karşılığında çıkması ve 'çini' alanındaki ilk araştırmaların, yayınların Fransızca ve Almanca olması gösterilebilir. 'Fayans ve çini' kelimelerinin ortak anlamda kullanılmaları başka bir çalışma konusu olabileceği için, burada konuya kısaca değinilmiştir.

\section{Sonuç}

‘Çini’ kelimesi, Türk yönetiminde Çin porseleni benzeri, fritli çamur veya yerel çömlekçi (seramik) çamuru üretim teknikleri ve Çin porseleni benzeri olmayan, fakat bu tekniklerle üretilen yerel kültürü yansıtan bezeme anlayışında üretilmiş sırlı mimari ve kullanım seramiklerini kapsamaktadır. Ancak, geçmişe ait sırsız seramikler ile sırlı seramikler, kültürün maddi öğeleri oldukları ve üretildikleri dönem içinde teknik ve görsel açıdan bir bütün oldukları için, dönemleriyle beraber değerlendirilmelidir. Böylece, yukarıda sınırlandırılan Geleneksel Türk Saray seramiği ile geleneksel çömlekçi ürünleri alanında araştırma yapılan Geleneksel Türk Sanatları Bölümü Çini Anasanat Dalı programlarında 'çini' kelimesi, Geleneksel Türk seramiğini kapsamaktadır.

Belgelerde de görüldüğü gibi, erken dönemlerde sadece Çin porseleni ile Çin porseleni benzeri yerel üretim kullanım eşyaları için kullanılan bir kelimenin, Türkiye Cumhuriyeti döneminde sadece mimari seramikler olarak tanımlanması nedeni ile oluşan kargaşa sonucu günümüzde kelimeye yeni anlamlar yüklenmektedir. Yazılı belgelerin kullanım eşyalarını, günümüz tanımlarının ise mimari seramikleri nitelemesinin yanı sıra, yabancı kaynaklardan yapılan çeviriler, 'çini' nin kapsamını çeşitlendirmektedir. Ayrıca, Osmanlı döneminde, Avrupa’nın desteği ile yapılan porselen üretiminin, 'Yıldız Çini Fabrikası' adıyla başlaması ve 'çini' kelimesinin Türkçe'de de Avrupalıların kullandığı anlamda 'porselen'i niteleyen anlamda kullanılması gibi nedenler, 'çini' alanında çalışanların 'çini' kelimesini ortak anlamda kullanamaması ile sonuç- 
lanmıştır. Bu kargaşayı düzeltmek, bu alanda çalışanların, alanlarını daha iyi tanımlamasıyla daha doğru bilgilerin üretilmesiyle sağlanacaktır.

Geleneksel Türk sanatları kapsamında ‘Çini’ kelimesinin yabancı bir kültürde ifadesi için başka bir dile çevirisinde, kelimenin, Türk yönetiminde üretilen, porselen, seramik kullanım eşyası ve mimari plastik öğeler anlamını kapsayan, yabancı bir kelime ile karşılaşılmamıştır. Dolayısıyla değiştirilmeden 'çini' (traditional Turkish ceramic) veya 'Turkish chinoiserie’ olarak çevrilmesi gerektiği düşünülmektedir.

Kullanım seramiklerindeki üretim tekniğinde çeşitlilik nedeni ile bu ürünlerin, teknik farklılıkları veya üretim yerleri ile dönem belirterek tanımlanması, İznik Beylikler Dönemi seramiği, fritli çamur İznik seramiği, kırmızı çamur İznik seramiği veya çinileri gibi adlandırmalar ile 'çini'ye ilişkin kargaşanın azalması sağlanabilir.

Günümüzde 'çini' kelimesinin sadece 'desen, motif' anlamında, özellikle de 'Osmanlı nakkaşhane desenleri'ymiş gibi -çini deseni- ifadesinde kullanılması ve çeşitli yanlış sınırlarla tanımlamaya çalışmak, bu çaış̧mada belirtilen belgelere göre anlamsız kalmaktadır. Zaten bir pişmiş toprak türü olan 'çini’nin, -çini ve seramik- ifadesinde, bir arada kullanımı ve Kütahya malzemesine (çamuruna ve sırına) adını vermesi devam ettiği sürece 'çini' kelimesi, bu alanda üretenler, araştıranlar ve uzmanlaşanlar arasında ortak bir anlamda kullanılamayacaktır. 'Çini' kelimesinin günümüzdeki anlamının, sanat tarihi, dil bilimi gibi farklı uzmanlıklar tarafından değerlendirilerek, ortak olarak kabul edilebilecek sınırlamalar ile tanımlanması gerekmektedir.

\section{Notlar}

1 Geçmişteki ve günümüzdeki üretim yerlerini çoğaltmak mümkündür. Yukarıda en popüler olan üretimler belirtilmiştir.

2 fağfuri: Osmanlılarda, başlangıçta Çin Imparatorunu tanımlamak için kullanılırken, sonraları Çin porselenlerinin genel adı olmuştur (Raby, 1986: 82; Küçükerman, 1987: 31).

3 mertebani: Burma'daki Martaban Limanı, Çin seramik ve porselenlerinin Hindistan'a, Afrika'ya, Yakın Doğu'ya deniz yoluyla gönderildiği en büyük çıkış noktasıydı. Anadolu'ya bu yolla gelmiş olan pişmiş toprak ürünler de genel bir tanımlamayla 'Mertebani' olarak tanımlanmıştır (Küçükerman, 1987: 37).
4 alaca sözcüğünün Çin porselenleri söz konusu olduğunda, "mai nakışlı beyaz" gibi mavi-beyaz anlamına geldiğini belirtir (Yücel ve Raby, 1986: 68).

5 meksur ya da şikeste: kırık kaplar (Atasoy, 1989: 37).

6 evani: kapkacaklar, kaplar (Devellioğlu, 1978).

7 beçkari: Viyana porseleni (Raby ve Yücel, 1986: 53).

8 Alıntı yapılan İngilizce metinde, "çīnī (China veya Chinaware)" olarak görülmektedir (Raby, 1986: 82).

9 “ibn al- Baytār (1197-1248), fındık kabuğunun pürüzsüzlüğünü tanımlarken porselen hammaddesi gibi (ghadār şīnī)" diye belirtmektedir (Milwright, 1999: 514).

10 "Kazaklarda çay, ... 'şını' denilen büyük porselen fincanlarla servis yapılır." (Duman, 2008: 161).

11 "China: 1. su emmesi \% 1 civarında çoklukla saydam porselen bünye. 2. sert pekişmiş ve beyaz pişen bünye. 3. ticari anlamda sofra eşyasına verilen genel ad.China clay: kaoline verilen diğer ad, çok özlü olmayan, yüksek ısıya dayanıklı, pişme rengi Beyaz, primer veya seconder kil. China paint: pişmiş sırlı yüzeylerde genellikle porselen dekorlama da kullanılan düşük dereceli boyalar. Emaye." (Peterson ve Peterson; 2009: 224).

12 Örneğin, İstanbul Çinili Köşk’ün özgün adı olan "Sırça Saray da, İran'da 'çini' için kullanılan 'kaşi’ yerine, Konya yöresinde çini- işi demek olan 'sırça' sözünün kullanılması, Karaman Beyliğinden mimarları akla getirmektedir.” (Necipoğlu, 2007: 270).

13 Kaşi: “íran'ın Kaşan şehrinde yapılan bir çeşit çini, çini fayans." (Devellioğlu, 1978: 211-212).

14 "Çin porselenleri, her zaman yerel seramiklerden daha değerlidir. Porselenin tınlamalı sert maddesi, beyazlığı ve yarı şeffaflı̆̆ı nedeniyle Arap yazarlar tarafından da özellikle beğenilmektedir." (Lane, 1971: 21).

15 “Floransa Dükü’nün öncülüğünde, 1575 yılında, Avrupa'nın ilk protoporseleni olan 'alla porcellano', 1664 ‘te ise ‘sırçalı porselen', Paris'te üretilmişti.” (Arcasoy, 2000: 72).

16 Örneğin Golombek, (1996: VII) “Timur Dönemi seramiklerini çalışmaya başladıklarında, Mavi Beyaz Çin porseleni taklit üretimler olmaları dışında bir bilginin bulunmadığını" belirtmektedir. "Abbasi İmparatorluğu'nda Yerel çömlekçilerde porselen hammaddesi bulunmadığından, Çin porselenlerine benzemesi için örtücü beyaz bir sır kullandılar." (Hattstein ve Delius: 122). "Avrupa porselenlerinin ilk örnekleri, özellikle süsleme açısından Çin porseleninin etkisi altındadır." (Küçükerman, 1987: 23). "Birleşik Doğu Hindistan Kumpanyası'nın geniş ölçekteki Çin porselenleri ithalatı Delft seramiklerinin görünüşünü çarpıcı biçimde değiştirmişti. Delft'te üretilen çanak çömlek 17. yüzyıla kadar çok renkli ve görece kabaydı, ama piyasanın güzel Çin porselenleriyle dolması, ülkedeki seramik atölyelerini ürünleri gözden geçirmeye zorladı." (Sabancı Müzesi, muze.sabanciuniv.edu, 2012).

17 “Çin İmparatoru Hongwu ve Yongle’nin (1403- 1424) 
krallık mezarlarında mavi beyazın olmaması, Çin'de bu ürünlerin bu dönemde üst sınıf tarafından düşük değerde kabul edildiğini doğrulamaktadır." (Bailey, 1996: 9).

18 "Milet işi olarak bilinen, erken Osmanlı Dönemi İznik seramikleri ve bu teknikte üretilen ürünler günümüzde, İznik Beylikler dönemi olarak adlandırılmaktadır." (Eren, 2006: 554).

19 "Tekfur Sarayı ve çevresinde çiniciliği geliştirme çalışmaları için, 1719 yılında, İznik Naibi'ne yazılmış olan bir karar özetle şöyleydi: “eskiden bu yana İznik’teki çini atölyelerinde güzel çiniler üretip İstanbul'a gönderiliyordu ve saray ile önemli dini yapılarda kullanılıyordu. İki seneden beri bu ustalar üretimi kesmiş, işi ve işyerlerini terk etmiştir. Bu uygun bulunmadığı için, bu emre uyarak İnik'te kaç çini atölyesi olduğunu belirlemek ve saray mimarları ile birlikte birer örnek seçerek gereken yapılmalıdır. Ama bütün bu girişim ve düzenlemelere karşılık sorun çözümlenememiştir." (Küçükerman, 2007: 169).

20 “Maqrizi, Kahire'de 1338'de bir "qādī”nin kendi Çin vazosu (awānī al şīnī) koleksiyonunun satışından 40.000 dirhams kazanabileceğini kaydetmiştir." (Milwright, 1999: 514). "1348'de 'siniyyi' Şam'da, Çin porseleni tabağı anlamındadır." (Carswell, 2000: 56). "Ibn Batuta, Şam'da, sokakta, porselen bir çanağı (safha mina 'l-fakhkhār al şīnī) kıran servis elemanı hakkındaki dramadan bahsetmektedir." (Milwright, 1999: 513).

21 “Naqqash Hajji Muhammad'e ek olarak 16. yüzyılda Heratlı iki çömlekçi daha kayıt edilmiştir. "...Safa chini (fritli çamur) üretiminde ustalaşmıştı...” (Golombek, 1996: 133).

22 Örneğin: "Ibn Taghribirdi, 1450 de ki bir düğünde eşyaları kaydetmişti. Bu kayıtta giysiler, brokarlar, kürkler, kristal eşyalar, değerli metal uygulamaları ve yazılı porselenlerin iyi örneklerini (al- tuhaf mina 'l-şīniyyil-mukattabi) içeriyordu." (Milwright,1999: 515).

23 “Avrupa porselenleri genellikle 'Viennese’ veya 'Saxon işi' gibi, menşei ile belirtilmektedir." (Yücel ve Raby, 1986: 70).

24 Örneğin: (Devellioğlu, 1978: 191), (İslimyeli, 1973: 134.), (Sami Efendi: 533), (Pakalın, 1993: 374).

25 Benzer tanım için ayrıca bkz.: Meydan Larousse, 1970: 268

26 Birinci Milletlerarası Türk Çini ve Seramik Kongresi: özetler, İstanbul Edebiyat Fakültesi Basımevi, 1986.

27 “Osmanlılar çini (Çinli) sözcüğünü kilden yapılan her türlü kap için kullanmıştır. Dolayısıyla kullanımı büyük ölçüde İngilizce'deki 'China' (Çin) yani nitelikli yemek takımı ile aynıdir." (Atasoy, 1989: 25).

28 China: Çin, çini, porselen, porselen kap, chinaware porselen, seramik, china closet tabak dolab, çanak çömlek, porselen türünden kap, kacak, fayans, zücaciye (İngilizce- Türkçe sözlük, seslisozluk.com, 2009a)

29 China: (noun) clay of a high quality that is shaped and then heated to make it permanently hard, or objects made from this, such as cups and plates (İngilizce- İngilizce Sözlük, dictionary.cambridge.org, 2012).

30 tile: çini, kiremit, fayans, karo, fayans döşemek, mason locasında kapıda durmak, döşe, tuğla döşemek (yer), 1- (damı) kiremitle kaplamak. 2- Künk, seramik, çatı üzerine kiremit yerine konan demir veya taş parçası, dili silindir şapka, mason locasında kapıcılık etmek, duvar çinisi, Taş, yassı tuğla, silindir şapka, çini vb ile kaplamak, gizli tutmak, karo fayans, karo seramik, karo mozaik; çini, Kep, tuğla (yassı) to tile: çini döşemek, kiremitle kaplamak, karoyla kaplamak... (İngilizce- Türkçe sözlük, seslisozluk.com, 2009c)

31 encaustic: 1. Renkli mumlar ısıtılarak boyanmış (kiremit, çini v.s.), 2. Renkli mumları bir yüzeye sürüp ısı ile sabitleştirerek yapılan bir boyama metodu (İngilizce- Türkçe Langenscheidt Satandard Sözlüğü: 1983: 166).

32 Glost: çini, çanak çömlek imalâtında kullanılan kurşun sır (İngilizce- Türkçe sözlük, seslisozluk.com, 2009b).

33 Chinoiserie: resimde ve dekorasyon eşyasında Çin motiflerini taklit etme (İngilizce- Türkçe sözlük, seslisozluk.com, 2012). Fransızca da chinoiserie [la] Çin işi biblo; karışık garip iş (Fransızca Türkçe Sözlük, fransizcasozluk.gen.tr, 2012a).

34 National Palaces Yıldız Porcelain and Tile Factory- olarak çevrilmiştir; Milli Saraylar Yıldız Çini ve Porselen İşletmesi Kataloğu, 2007. İstanbul: TBMM Milli Saraylar Daire Başkanlığı Kültür Tanıtım Başkan Yardımcılığı Yayın- Tanıtım Bölümü.

35 Etymology: [ shEn-'wäz-rE, -'wä-z ] (noun.) 1883. From French chinoiserie ('Chinese-esque') (İngilizce- Türkçe sözlük, seslisozluk.com, 2012)

36 Chinoiserie: Avrupa Sanatında 18. yüzyıldan başlayarak yaygınlaşan ve Çin sanatı'na öykünen bir akım ve bu akımın çizgisi doğrultusunda oluşturulmuş sanat ürünleri. Chinoiserie 19. yüzyılın sonunda ortadan kalkmıştır.

\section{Kaynakça}

Altındağ, Ülkü ve Bayraktar, Nedret (1987). “Topkapı Sarayı Müzesi Tahrir Komisyonu Çalışmaları 1”. Topkapı Sarayı Müzesi Yıllık 2, İstanbul: Topkapı Sarayı Müzesi Müdürlüğü, s: 7- 61.

(1988). “Topkapı Sarayı Müzesi Tahrir Komisyonu Çalışmaları 2”. Topkapı Sarayı Müzesi Yıllık 3, İstanbul: Topkapı Sarayı Müzesi Müdürlüğü, s: 23- 61.

Altun, A., Carswell, J., Öney, G. (1991). Türk Çini ve Seramikleri, İstanbul: Sadberk Hanım Müzesi.

Ana Britannica Genel Kültür Ansiklopedisi, (1992). Ana Yayıncılık, (6):476.

Anadolu'da Türk Devri Çini ve Seramik Sanatı (2007). editörler: Gönül Öney ve Zehra Çobanlı, İstanbul: T.C. Kültür ve Turizm Bakanlığı Yayınları.

Arcasoy, Ateş (1982). "Seramiğin Tanımı ve Porselene Geçiş", Antika (29): 16- 26. 
(2000). "Sevres ve Paris Porselenleri”, Antik Dekor (59): $72-91$.

Aslanapa, Oktay (1997). Türk Sanatı, İstanbul: Remzi Kitabevi.

Atasoy Nurhan (1989). "Osmanlı Belgelerindeki İznik Seramikleri”. İznik, London: Alexandria Press, Türk Ekonomi Bankası Yayını, s: $25-32$.

(1989). “iznik Çinilerinin Türleri ve Biçimleri”. İznik, London: Alexandria Press, Türk Ekonomi Bankası Yayını, s: 37- 48 .

Bailey, Gauvin A. (1996). "The Stimulus: Chinese Porcelain Production and Trade with Iran". Tamerlane's Tableware- A New Approach to The Chinoiserie Ceramics of Fifteenth and Sixteenth Century Iran, USA: Mazda Publishers in association with Royal Ontario Museum. s: 7- 15

Barbaro, Josaphat (2009). Anadolu'ya ve Irran'a Seyahat, çev: Tufan Gündüz, İstanbul: Yeditepe Yayını (2. Baskı.)

Bayram, Sadi (1984). "Yıldız Çini Fabrikasına Ait Birkaç Vesika”. Suut Kemal Yetkin Anısına Armağan, Ankara: Hacettepe Üniversitesi Armağan Dizisi: 1, s: 101- 105.

Carroll, Lynda (1999). “Could've Been A Contender: The Making And Breaking Of "China" In The Ottoman Empire", International Journal Of Historical Archaeology (3/3): 177- 190.

Carswell, John (2000). Blue And White Chinese Porcelain Around The World, Chicago: Art Media Resources.

Chaffers, W. (1867). "Lectures on Pottery and Porcelain", Society of Arts (15): 433-435.

Devellioğlu, Ferit (1978). Osmanlıca Türkçe Lügat, Ankara.

Duman, Mustafa (2008). Çay Kitabı, İstanbul: Kitabevi Yayını.

Ebu Abdullah Muhammed ibn Battuta Tanci Ibn Battuta Seyahatnamesi (2010). çeviri, inceleme ve notlar: A. Sait Aykut, İstanbul: YKY, 484.

Eczacıbaşı Sanat Ansiklopedisi (1997). YEM yayınları.

Emerson, J., Chen J., Gates M. G., (2000). Porcelain Stories From China to Europe, WA: Seattle Art Museum.

Erdoğdu, Ayşe (2001). "The Place of Chinese Porcelains in Ottoman Daily Life" Chinese Treasures in İstanbul, ed. Ayşe Üçok, Istanbul: The Ministry of Foreign Affairs of the Republic of Turkey, s: 102- 129.

(2003). “Mavi Beyaz Hazine”, Antik Dekor (77): 88 - 96.

Eren, Ayça (2006). “Iznik Beylikler Dönemi Seramik Kaselerinin Genel Özellikleri ve Bu Döneme Ait Yeni Bir İznik Kazı Buluntusu Çanak Örneği”, 6. Uluslararası Katılımlı Seramik Kongresi Bildiriler Kitabı, İstanbul: Türk Seramik Derneği
Yayınları (23), s: 554- 559

Golombek, L., Mason, R. B., Bailey, G. A. (1996). Tamerlane's Tableware A New Approach To The Chinoiserie Ceramics of Fifteenth And Sixteenth Century Iran, USA: Mazda Publishers in association with Royal Ontario Museum.

Golombek, Lisa (1996). “The Ceramic Industry in Fifteenth- Century Iran: An Interpretation", Tamerlane's Tableware- a new Approach to The Chinoiserie Ceramics of Fifteenth and Sixteenth Century Iran, USA: Mazda Publishers in association with Royal Ontario Museum, s:124- 139.

Hattstein Markus ve Delius, Peter (2000). Islam Art and Architecture, Könemann.

Henderson, Julian ve Raby, Julian (1989). "The Technology of Fifteenth Century Turkish Tiles: An Interim Statement On The Origins of The Iznik Industry", World Archeology, (21/1): 115132.

Şeker, Mehmet (2001). Ibn Batuta'ya Göre Anadolu'nun SosyalKültürel ve iktisadi Hayatı ile Ahilik, Ankara: T. C. Kültür Bakanlığı Yayınları.

İslimyeli, Nüzhet (1973). Sanat Terimleri Ansiklopedisi, Ankara: Sanat Yayınları: 5.

Keribar, İzzet (1998). “Eski Viyana (Alt Wien) Porselenlerinde Dönemler", Antik Dekor (46): 82- 90.

Krahl, Regina (1986). Chinese Ceramics in The Topkapı Saray Museum Istanbul- A Complete Catalogue, London: Sotheby's Publications, Topkapı Saray Museum.

(2001). "The Chinese Porcelain in Topkapı Sarayı", Chinese Treasures in Istanbul, ed. Ayşe Üçok, İstanbul: The Ministry of Foreign Affairs of the Republic of Turkey, s: 40101.

Kut, Günay (2010). “Osmanlı Saray Düğünlerinin Ziyafet Sofraları”, Yemek ve Kültür (19): 75- 94.

Küçükerman, Önder (1987). Dünya Saraylarının Prestij Teknolojisi ve Yıldız Çini Fabrikası, İstanbul: Sümerbank Yayınları.

(2002). “Saray Bahçesindeki 'Yıldız Fabrika-i Hümayunu' ve 110 Yıllık Porselen Koleksiyonu", Antik Dekor (70): 78- 90 (2007). Bir Imparatorluk Iki Saray, İstanbul: Yapı Kredi Yayınları.

Lane, Arthur (1948). Early Islamic Pottery, New York: D. Van Nostrand Company, INC.

(1971). Later Islamic Pottery (second edition). London: 
Faber and Faber.

Langenscheidt Standard Sözlüğü Ingilizce- Türkçe - Ingilizce (1983) yazan: Resuhi Akdikmen, yardımcı yazar: Ekrem Uzbay, Inkılap Kitabevi.

Mason, Robert B. ve Tite, M. S. (1994). "Islamic Pottery: A Tale of Men and Migrations", Museum International (46/3): 33- 38. Volume 46 - issue 3

Meydan Larousse, (1970). İstanbul: Meydan Yayınevi.

Milwright, Marcus (1999). "Pottery in the Written Sources of the yyubid-Mamluk Period (c.567-923/1171-1517)”, Bulletin of the School of Oriental and African Studies (62/3): 504-518.

Mimar Şehabeddin (1930). Selçuki ve Osmanlı Çinileri İşçiliği, Türk Çinilerinin menşeine ve muhtelif devirlerdeki tatbikatına dair tarihi tetkikler, İstanbul: Kainat Kitaphanesi.

Necipoğlu, Gülru (2007). 15. ve 16. Yüzyılda Topkapı Sarayı Mimari, Tören ve Iktidar, çev: Ruşen Sezer, İstanbul: Yapı Kredi Yayını: 2428.

Öney, Gönül (1987), “Erken Donem Anadolu Türk-İslam Seramiği (12 -13. yy.)", Antika (27): 16- 22.

(1987). İslam Mimarisinde Çini, İzmir: Ada Yayınları.

Özlük, Nuran (2008). “Selçuki ve Osmanlı Çinileri İşçiliği”. Türkiyat Araştırmaları Dergisi (23): 301- 328.

Pakalın, Mehmet Zeki (1993). Osmanlı Tarih Deyimleri ve Terimleri Sözlüğü 1, İstanbul: Milli Eğitim Bakanlığı yayınları: 2505, Bilim ve Kültür Eserleri Dizisi: 646, Sözlük dizisi: 2.

Pala Çalışıcı, İrem (2006). “Osmanlı Dönemi İznik Fritli Çamuru Iile Tebrizli Ustaların Fritli Çamuru Arasındaki İlişkiye Dair Belgeler", Uluslararası Geleneksel Sanatlar Sempozyumu Bildiriler Kitabı: 1, İzmir, s: 313-317.

(2009). “Osmanlı İmparatorluğu'nda Saray Mutfağında Kullanılan Bazı Pişmiş Toprak Kap Adları”, 10. Ulusal El Sanatları Sempozyumu Bildiriler Kitabı, İzmir, s: 323- 335.

Peterson, Susan ve Peterson, Jan, (2009). Seramik Yapıyoruz, çev: Sevim Çizer, İzmir: Karakalem Kitabevi Yayınları.

Raby, Julian (1986). "Fağfur, Merteban And Other Terms For Porcelain And Celedon", Chinese Ceramics In The Topkap saray Museum Istanbul, A Complete Catalogue, London: Published in association with The Directorate Of The Topkapı Saray Museum By Sotheby's Publications, s: 82-85.

Raby, Julian ve Yücel, Ünsal (1986). “Chinese Porcelain At The Ottoman Court”, Chinese Ceramics In The Topkapı Saray Museum Istanbul- A Complete Catalogue, London: Topkapı Saray Museum, Sotheby's Publications, s: 27- 54.

Refik, Ahmet (1932). “iznik Çinileri (Hazinei Evrak Vesikalarına Nazaran)”. Darülfünun Edebiyat Fakültesi Mecmuası, 8 (4): 36 55.

Roux, Jean-Paul (2001), Orta Asya, çev: Lale Arslan, İstanbul:
Kabalcı Yayınevi.

Sadberk Hanım Müzesi (Arkeoloji ve İslam- Türk Bölümleri) Kataloğu, (1995). İstanbul, Vehbi Koç Vakfı Yayını.

Sami Efendi, Kamus-ı Türki (Osmanlıca- Osmanlıca Sözlük), İstanbul: Dersaadet, 1317 Tarihli Akdem Matbaası, çev: Öğr. Gör. Özkan Birim, s: 533.

Sonat, Göksen (2005). “Topkapı Sarayı Müzesi'ndeki Osmanlı Zevkiyle Yapılmış Avrupa Porselenleri”, Osmanlı Sarayında Avrupa Porselenleri, İstanbul: Sabancı Üniversitesi Sakıp Sabancı Müzesi, s: 13- 19.

Soustiel, Laure (2000). Osmanlı Seramiklerinin Görkemi, İstanbul: Vehbi Koç Vakfı Yayını, Suna-İnan Kıraç Akdeniz Medeniyetleri Araştırma Enstitüsü: 7.

Sözen, Metin ve Tanyeli, Uğur (1994). Sanat kavram ve Terimleri Sözlüğü, 3. Baskı, İstanbul: Remzi Kitabevi.

Şahin, Faruk (1983). Seramik Sözlüğü, İstanbul: Anadolu Sanat Yayınları.

Tufan, Ömür (2005). "Osmanlı Sarayının Porselenleri Ve Avrupa'da İmalathaneler", Osmanlı Sarayında Avrupa Porselenleri, İstanbul: Sabancı Üniversitesi Sakıp Sabancı Müzesi, s: 2129.

Ünal, İsmail (1963). “Çin Porselenleri Üzerindeki Türk Tarsiatı”, Türk Sanatı Tarihi, İstanbul: G.S. Akademisi, Türk Sanatı Tarihi Enstitüsü Yayınları: 1, s: 677- 714.

Yıldırım, Leyla ve Erdem İşmal, Özlenen (2010). “Avrupa Dekoratif Sanatlarındaki Chinoiserie etkisinin tekstil Baskıcılığındaki yansımaları", Yedi: (3): 31- 36

Yücel, Ünsal ve Raby, Julian (1986). “The Archival Documentation”. Chinese Ceramics in The Topkapı Saray Museum IstanbulA Complete Catalogue, ed. Regina Krahl, London: Sotheby's Publications, Topkapı Saray Museum, s: 65- 81.

\section{Internet Kaynakları}

(Almanca Türkçe Sözlük, almancasozluk.web.tr, 2012) http:// www.almancasozluk.web.tr/index.php?q=Keramik\&pg=0 (10. 06. 2012).

(Fransızca Türkçe Sözlük, fransizcasozluk.gen.tr, 2012a) http:/ www. fransizcasozluk.gen.tr/sozluk.php?word=chinoise $(10$. 06. 2012).

(Fransızca Türkçe Sözlük, fransizcasozluk.gen.tr, 2012b) http:// www.fransizcasozluk.gen.tr/sozluk.php?word=fa\%EFence (10. 06. 2012).

(Ingilizce- İngilizce Sözlük, dictionary.cambridge.org, 2012) http:// dictionary.cambridge.org/dictionary/british/china?q=china (10. 06. 2012).

(İngilizce- Türkçe sözlük, seslisozluk.com, 2009a) http://www. seslisozluk.com/? word =china\&ssQBy=0 (26. 09. 2009) 
(İngilizce- Türkçe sözlük, seslisozluk.com, 2012) http://www. seslisozluk.com/?word=chinoiserie\&ssQBy=0 (10. 06 . 2012).

(Ingilizce- Türkçe sözlük, seslisozluk.com, 2008) http://www. seslisozluk.com/?word=chinoiserie\&ssQBy=0 (30.11. 2008).

(Ingilizce- Türkçe sözlük, seslisozluk.com, 2009b) http://www. seslisozluk.com/? word=glost\&ssQBy=0 (26.09. 2009).

(İngilizce- Türkçe sözlük, seslisozluk.com, 2009c) http://www. seslisozluk.com/?word=tile\&ssQBy=0 (26. 09. 2009).

(Sabancı Müzesi, muze.sabanciuniv.edu, 2012) http://muze. sabanciuniv.edu/rembrandt/sayfa/baharat-kabi (9. 06. 2012).

(Sevres ceramique, sevresciteceramique.fr, 2012) http://www. sevresciteceramique.fr/site. php?type=P\&id=263 (10. 06 . 2012).

(Türk Dil Kurumu Sözlüğü, tdk.gov.tr, 2008) http://tdkterim.gov.tr/ bts/?kategori=veritbn\&kaelimesec $=76902$ (30.10. 2008).

(Wikipedia, tr.wikipedia.org, 2008) http://tr.wikipedia.org/ wiki/\%C3\%87ini (30. 10. 2008). 